\title{
The Financial Performance of International Takeovers of the State-owned Companies: Evidences from Indonesia after the 1997/1999 Asian Crisis
}

\author{
Moh Gudono ${ }^{1, *}$, Lina Anatan ${ }^{2}$ \\ ${ }^{1}$ Department of Accounting, Faculty of Economics and Business, Gadjah Mada University, Indonesia \\ ${ }^{2}$ Department of Accounting, Faculty of Economics, Maranatha Christian University, Indonesia
}

Copyright (C) 2015 by authors, all rights reserved. Authors agree that this article remains permanently open access under the terms of the Creative Commons Attribution License 4.0 International License

\begin{abstract}
The objective of this study is to examine the financial performance of state-owned and non state-owned enterprises that were sold to foreign investors, i.e. International acquisitions, in the years 2000-2010. This research is driven by a number of controversies over the sale of Indonesian state enterprises to foreign investors that allegedly have been done under the pressure of IMF and that were suspiciously priced below the companies real market values. Many people oppose the sale because these companies carried Indonesia government bonds that were given as liquidity bailed-out during the years of crisis between the year of 1998 and 2000. Performance comparison could show whether the sale to foreign investors brought economic benefits as expected. To measure the performance of cross border acquisition this research used both accounting data and capital markets based measures. Samples were matched according to characteristics of companies being analyzed: financial (banks) institutions vs. non-financial companies and pure private vs. state-owned companies. The purposive sampling method was applied. Financial ratios and cumulative abnormal returns of fifteen acquired companies between the years 2000-2010 were examined. The final sample consists of sixty firm-year data. The results indicate that, as hypothesized, there is no performance improvement on state-owned banks acquired by foreign investors. On the other hand, state-non bank companies show significantly different improvement in performance compared to private banks and private-non bank performance. In general, these studies support the notion that politics may play role on the sale of state-owned bank after crisis period (2000-2010). Further investigation is needed to elaborate the findings.
\end{abstract}

Keywords Acquisition, International Takeover, Political Costs, Company Performance

\section{Introduction}

In the mid 1997s many Asian countries suffered from monetary crisis as a result of devastating currency rate fluctuations. Among the Asian countries in crisis Indonesia was probably the most affected by the financial crisis causes political turmoil and economic impoverishment. President Suharto who has been in power since 1966, finally fell after a massive demonstration on May 20, 1997 and Indonesia entered the reform era. At the end of his era, to rescue Indonesia economy Suharto signed an economic assistance agreement with IMF which later the monies would be used improve liquidity in the banking industry (BLBI).

The financial assistance was accompanied by some of the requirements stated in the LOI (letter of intent) that basically contained IMF request for Indonesia government to liberalize its country economy. From the standpoint of the IMF, the LOI was purely formulas to implement neoliberal economy principles [8] and that was considered to be important for Indonesia's economy immediate recovery. Many economic observers and NGOs protest the IMF recipes that force Indonesia to enter into global economy competition while Indonesia companies were not really ready. To implement the IMF loan requirements, President Megawati, who was in power five years after Suharto fall, finally agreed to sell several state-owned enterprises to private parties. Note that this move seems to be consistent with neo liberalism economy doctrines that the government should reduce interference in business life, because, the interference would simply create destruction and consequently would create economic inefficiency [8].

The sale of some state-owned enterprises has created a lot of criticism. Firstly, critics attacked the problem of assessment and argued that the selling price was too cheap. All state enterprises that were sold were indeed highly profitable companies but they were undervalued. For example, BCA selling prices are several times the amount of BCA's annual earnings. The second criticism questioned aspects of the national interest that was sacrificed because of all the state-owned company eventually fell on foreign 
investors. The critics argue that some companies were still holding government bonds (recapitalization bonds). If the company were sold to foreign investors then it means the government owes to foreigners and the interest charged to foreigners [12].

Although the policy (i.e., selling state-owned enterprises) is controversial, comprehensive research on the effects of the acquisition on the performance of these companies has not yet been done. The public certainly hope that after the companies being acquired by some foreign companies the Indonesia formerly state-companies financial situation would be better. Foreign Investor may have a better financial capability and have better managerial skills in managing the company so they are able to execute better business strategies.

Given the argument, the study tested whether the acquisitions done by foreign parties bring benefits in terms of improved financial condition. Foreign investors who have excess funds may be interested in buying assets in Indonesia when it was undervalued as a result of the economic crisis. They may be more interested in short-term gains from rising stock prices of the company's performance or creating synergies in the long run.

During monetary crisis, the banking companies commonly face a liquidity problem but they are able to adapt faster than other industries to exploit opportunities from exchange rate volatility. Hence, many companies in the banking industry gain higher profitability during monetary crisis. By contrast the performance of non-financial companies more difficult to predict.

The study of the impact of transnational acquisitions on performance is important to gain understanding about the effects of not only some economic factors but also cultural and political factors $[18,15]$. Wan and Wong [16] concluded that the political opposition to international takeovers may adversely affect the market value of domestic firms in two aspects. First, the political obstacles to acquiring foreign companies can reduce the possibility of takeovers. Thereby reduction in takeover premium is expected. According to Eun et al., [3] and Harris and Ravenscraft [5], the share price of target companies reacts well to the announcement of the international takeover and creates barriers to foreign acquirers and that finally reduce the potential bidders for domestic target companies. Second, these barriers may hamper the potential benefits derived from international takeovers. This argument is supported by Marr et al. [10] who provide evidence that a foreign bidder can increase competition in the market for corporate control.

Since financial institutions were the one that received greater proportion of IMF monies during the monetary crisis of the year 1998-2000 and the sale of the companies have created heated controversy, the focus of this research is on the performance of international takeovers in banking industry. However, in doing so other types of industry as well as type of ownership (non-state-owned) were also investigated. The purpose of this study is to examine whether there are differences in acquisition performance between state-financial institutions vs. non-state-nonfinancial institutions. Compared to prior cross border merger and acquisition studies, the unique features of this research are twofold. First, the focus other this study is on the sale of state-owned companies, rather than private companies. Politics may also play role. Hence, richer theories are consequently needed. Second, from methodology standpoint, this study applied a quasi-experimental design to neutralize the effect of ownership and industry in the hypothesis testing. Lastly, this research used accounting measures to investigate the performance of international takeover during economic crisis. Today (2011-2012) we once more witness almost similar financial crisis happening across Europe. Indonesia experience regarding the effect of state-owned company sales could provide important lesson to European countries and similar measures might be used.

The rest of this paper would be organized as follows. Section II discusses the literature review and key concepts. Section III discusses the research models and the hypotheses of this study. Section IV presents empirical evidence on international takeovers between private and non-private companies in the period of cover Section V discusses the conclusions of this study.

\section{Literature Review and Key Concepts}

Political theory can be defined as a discipline that aims to explain, justify, or criticize the disposition of power in society, describing the balance of power between 'force' states, groups and individuals. Word in this definition is widely used: even obedience is the aspect of power. Power lies in the resources (personal, economic, moral, ideological, etc.), and operates through persuasion, threats and taxes as well as the deployment of resources. The analysis from political perspective might help to answer these questions logically, and criticized the other answers given, with a deal on political issues at a more abstract and general. A political theory can be used to test the national factors to explain the acquisition of cross-national pattern of state and analyze the strategies of relevant actors. Based on research on international takeovers, strategy, culture, and politics contribute to the implementation of international takeovers, and above all, politics has contributed greatly to the final acquisition policy.

The analysis of trend in international takeovers plays an important role in explaining the current economic phenomenon, e.g., international takeovers, where economic-efficiency perspectives and political factors gained public attention [9]. In this circumstance, acquisition strategies would be dominated by political economy reasons and efficiency would be of secondary importance. Wide variation of foreign ownership of a company's assets in developing countries is largely driven by political actors to pursue domestic strategies and objectives. Politicians have the power to influence the redistribution of wealth to the corporation by way of corporate taxes, regulations, and 
subsidies. In addition, certain groups of voters have an incentive to lobby for the expropriation, nationalization, break-ups or industry regulations or corporation which in turn will provide an incentive to politicians to propose such measures [17].

Based on Watts and Zimmerman's [17] work, Milne [11] concluded that despite the weaknesses of positive accounting theory as suggested by Gray et al. [4], political cost theory prediction upon corporate social behavior is valid. Focus of attention in political theory discussion is the public and politicians and their relationship with monopoly power. Environmental deterioration and other related problems such as resource depletion, labor exploitation, production of unsafe products, which are caused by big companies, have recently draw public and political attention. Those problems also represent the potential for abuse of power done by big companies and could increase what Watts and Zimmerman [17] mention as political costs. This makes these companies become clear targets for public criticism. Similarly, the next reference them in 1986 emphasized the attention of the press and politicians with a size advantage and potential monopoly abuse.

Entrepreneur politicians 1 could use their "financial advantage" from their private companies to boost their "political power" which later would likely benefit their private companies economically. The political behavior may include providing gratuity for both other politicians and civil servant bureaucrats. The expenses cover spending for managerial generosity, free help, providing sports membership, travel expenses for attending seminars, or simply cash. Western literatures may categorize those spending as "political costs" even though in many Asian countries the essence are totally different because the spending is political benefits and from accounting standpoint could create real future streams of cash inflows. The Indonesia corruption Law No 20 which was released in 2001 states that some gratuities are illegal. Nonetheless news media until recently still expose such kind of spending. Given the difference nature, a question may be raised whether the effects of political costs to management behavior from Western perspectives is relevant for the Indonesia case.

\subsection{Performance Measures}

Different measures of acquisition performance have been used in prior studies. For instance stock market returns of acquirers have been used in Carow, Heron and Saxton [1] and Datta and Puia [2]. On the other hand, accounting profitability measures have been used in (e.g.) Hitt, Harrison, Ireland and Best [6]. Schoenberg [13] argues that some of the conflicting conclusions within the acquisitions literature may

11 They are businessmen of small, medium, and big companies who choose to become politicians. In fact many Indonesia political party leaders are businessmen. For instance, Aburizal Bakrie (of Golkar), Surya Paloh (of Nasdem), Megawati (of PDIP), and Prabowo (of Gerindra). be due, in part, to the adoption of different performance metrics. Further, he cautions that inconsistent use of the available performance measures may have held back knowledge development (see also [7]). To avoid the problem, this study used both accounting measures (financial ratios) and stock returns to measure companies' financial performance.

\subsection{Accounting Measures}

Financial ratios show the relationship between numbers in the companies' balance sheet statement and income statement. Financial ratios that were used in this study include the following ratios:

a. Liquidity ratios, including: current ratio (CR) and quick ratio $(\mathrm{QR})$.

b. The ratio of activities, including: fixed asset turnover (FATO), and total asset turnover (TATO).

c. Leverage ratios, including: debt to total assets (DTA)

d. Profitability ratios, including: operating profit (OPM), net profit margin (NPM), return on investment (ROI) and return on equity (ROE).

Liquidity ratios measure a company's ability to meet immediate (short run) financial obligations. Liquidity ratio in this study includes current ratio and quick ratio. Current ratio is calculated by dividing current assets by liabilities lancer, while the ratio is calculated by subtracting Quick inventory of current assets and the remainder divided by current liabilities.

Activity ratio is a measure of how efficient is the company manages its assets. The ratio is measured by dividing various assets from total sales. Activity ratios used in this study include: fixed asset turnover and total asset turnover. Fixed asset turnover measures how effectively a company uses its fixed assets, calculated by dividing net sales by fixed sales. Total asset turnover measures the velocity of all assets, calculated by dividing the total sales and assets. Leverage ratio is calculated from the ratio of debt to total assets and capital of the company itself and the related guarantees, which measures the ability of companies to repay debt at a time when the company is liquidated or dissolved. In this study include the leverage ratio of debt to total assets ratio, which measures how much the entire debt secured by all assets of the company, calculated by dividing total liabilities by total assets.

Profitability ratios measure a company's ability to generate profits. The profitability ratios used in this study include: Operating profit margin, net profit margin, Return on Investment Return on Equity. These measures are probably viewed the important measures by public, since these measure are directly related with firms ability to create wealth to shareholders. Operating profit margin measures the number of operating income generated from the sales or income that is calculated by dividing operating profit by sales. Net profit margin measures how much net profit after tax and interest that can be generated from the sales or 
revenues, calculated by dividing the net profit to sales, return on investment measures the profit generated from all company-owned assets. Return on Equity (ROE) measures how much net income can be generated from the investment of shareholders in a company. ROE is calculated by dividing the net profit to equity owners.

\subsection{Stock Returns}

Stock returns are gains earned by stockholders and they represent shareholders' wealth. Stock returns were used to measure companies' abnormal returns (AR) which were basically differences between actual stock returns and expected returns. This study used the market model of stock returns [17]:

$$
\text { Rit }=\alpha \mathrm{i}+\beta \mathrm{i} . \mathrm{Rmt}+\varepsilon \mathrm{it}
$$

Where the Rit is monthly stock returns, Rmt is market returns (measured using IHSG, Indonesia composite index). To calculate AR we need to estimate $\alpha$ and $\beta$ of mode; (1) during estimation period and then we use both regression parameter to calculate AR (see also formula 2 and 3 below). The $\alpha$ is intercept of the market model and $\beta$ resembles the systematic risk. $\varepsilon i$ is a random error. Model parameters, $\alpha i$ and $\beta i$, are estimated by regression of Rit and the Rmt for the proper estimation period. The parameters then would be used to calculate the estimated normal returns $\mathrm{E}$ (Ri) for each firm $i$ during event windows. The abnormal earnings (AR) is defined as as follows:

$$
\begin{gathered}
\mathrm{AR}=\mathrm{Rit}-\mathrm{E}(\mathrm{Ri}) \\
\mathrm{AR}=\mathrm{Rit}-\{\alpha \mathrm{i}+\beta \mathrm{i} . \mathrm{Rmt}\}
\end{gathered}
$$

Most of the previous literature using monthly returns, this is because the monthly data has a higher consistency and supports a more stable parameter estimates or reliable. Empirical evidence from international studies from the United Kingdom and the United States show that in the short term, acquisitions would benefit more for the target company's shareholders. The wealth transfer from acquirer shareholders to acquired shareholders is consistent with Eun et al. [3]. This is due to overestimation made by acquirer firm managers when estimating the capacity of the target company to create value acquisition. In the long run, Tuch and O'Sullivan [14] showed that the acquirer's shareholder returns in the long term is negative. Theoretically, after the acquisition the company size increases because the assets, liabilities and equity firms are merged together. If the new management could really use the assets effectively then ceteris paribus post-acquisition performance should be better than before the acquisition.

\section{Research Model and Hypotheses}

While corporate managers have an incentive to choose accounting procedures and to lobby with the politicians and bureaucrats for accounting procedures that reduce the net income reported in financial statements, as discussed before the politicians have the power to influence them. According to Watts and Zimmerman [17], companies need the help of planning and advertising tools such as social responsibility in the media, including the government and to choose the accounting rules in order to report the minimum value of corporate profits and revenues. This strategy is important for the sustainability of the company because management can reduce the likelihood of different activities and reduce expected costs by reporting lower earnings [11]. Given this argument, the research hypothesis is stated as follows:

H1: There is no significant difference in cross border performance between state-owned financial companies and other type of companies (i.e., privately owned banks, state owned nonfinancial institutions, and privately-owned nonfinancial companies).

$\mathrm{H} 2$ : There is significant difference in cross border performance among state-owned non-financial companies, private financial companies, and private nonfinancial companies.

Given lack of prior research findings Hypothesis 1 (H1) is stated as the null hypothesis. We expect that the possibility of political costs in the highly regulated industry (such as banking industry) would reduce management motivation to attract attention from public and regulators. In this situation one of the alternatives that management likely to play is by averaging its performance. Nonetheless it is not managerial hubbrish type of action because in this situation management intentionally lowering or reducing performance different with other type of companies.

$\mathrm{H} 2$ is stated as an alternative hypothesis. Despite lack of prior research findings, there is strong argument that since state non-financial companies are regulated less compared to financial institutions (banks), their financial statements may reflect better the economics nature of the business. In such situation we expect that the performance measure being used in this study would capture the dynamic of the business. This hypothesis is a complement of $\mathrm{H} 1$. When the $\mathrm{H} 2$ is supported and when further post-hoc analysis suggests that the performance of state-owned nonfinancial cross border acquisition is higher, then the evidence is stronger that the state companies were sold too cheap.

\subsection{Sample and Data Collection}

The study population is all public companies listed in Jakarta Stock Exchange (JSE) in the 2000-2010 timeframe. This study applied a purposive sampling method. Since its focus is on international takeover, several criteria were developed for the acquired and the acquirer companies. Sample of acquiring companies (acquirers) were chosen based on the following criteria: a) acquisitions were done during the period 2000-2010 and have been listed on the Jakarta Stock Exchange (JSE), b) The acquirers are foreign companies and the acquired are local companies. The acquired companies must satisfy the following criteria: a) the 
company experienced a shift in the form of transfer of ownership of the stock ownership of more than $50 \%$ of the shares are acquired by another company. b) have a clear statement about when the company is acquired, c) have financial statement data and stock prices for a period of one to two years before and after the acquisition. Data and data sources used in this study is secondary data obtained from the data of financial statements and the company's stock price data sample comes from the Indonesian Capital Market Directory (ICMD) and Database Corner JSE MM-UGM.

Table 1. List of Sample Companies

\begin{tabular}{|c|c|c|c|}
\hline Classification & $\begin{array}{c}\text { Acquired } \\
\text { Companies }\end{array}$ & Acquiring Firm & $\begin{array}{c}\text { Month, Year } \\
\text { of } \\
\text { Acquisitions }\end{array}$ \\
\hline \multirow[t]{3}{*}{$\begin{array}{c}\text { State owned } \\
\text { - Bank }\end{array}$} & BCA & $\begin{array}{c}\text { Farallon } \\
\text { Capital-Led } \\
\text { Consortium }\end{array}$ & June 2002 \\
\hline & Bank Niaga & Commerce Assets & $\begin{array}{c}\text { November } \\
2002\end{array}$ \\
\hline & $\begin{array}{c}\text { Bank } \\
\text { Danamon }\end{array}$ & $\begin{array}{l}\text { Temasek Ied } \\
\text { Consortium }\end{array}$ & June 2003 \\
\hline \multirow[t]{4}{*}{$\begin{array}{l}\text { State owned- } \\
\text { Non Bank }\end{array}$} & Indosat & Qatar Telkom & June 2008 \\
\hline & PT Telkom & & $\begin{array}{c}\text { Desember } \\
2000\end{array}$ \\
\hline & $\begin{array}{l}\text { PT Semen } \\
\text { Cibinong }\end{array}$ & Holcim Ltd & $\begin{array}{c}\text { November } \\
2001\end{array}$ \\
\hline & $\begin{array}{c}\text { Indocement } \\
\text { Tunggal } \\
\end{array}$ & $\begin{array}{c}\text { Heidelberger } \\
\text { Zement AG }\end{array}$ & April 2011 \\
\hline \multirow[t]{4}{*}{$\begin{array}{c}\text { Non State } \\
\text { owned-Bank }\end{array}$} & Lippo Bank & $\begin{array}{c}\text { Khasanah } \\
\text { Nasional Berhard }\end{array}$ & August 2005 \\
\hline & $\begin{array}{c}\text { Bank } \\
\text { Tabungan } \\
\text { dan } \\
\text { Pembanguna } \\
\text { n Nasional } \\
\end{array}$ & $\begin{array}{c}\text { Texas Pasific } \\
\text { Group }\end{array}$ & March 2008 \\
\hline & $\begin{array}{c}\text { Bank } \\
\text { Permata }\end{array}$ & $\begin{array}{c}\text { Standart } \\
\text { Chartered Bank }\end{array}$ & $\begin{array}{c}\text { November } \\
2004\end{array}$ \\
\hline & $\begin{array}{c}\text { Bank } \\
\text { Internasional } \\
\text { Indonesia }\end{array}$ & Temasek & Oktober 2003 \\
\hline \multirow[t]{4}{*}{$\begin{array}{c}\text { Non state } \\
\text { owned - Non } \\
\text { Bank } \\
\end{array}$} & Bentoel & BAT & June 2009 \\
\hline & $\begin{array}{c}\text { HM } \\
\text { Sampoerna } \\
\end{array}$ & Phillip Morris & March 2005 \\
\hline & $\begin{array}{l}\text { Aqua Golden } \\
\text { Mississipi }\end{array}$ & Danone & April 2000 \\
\hline & $\begin{array}{l}\text { Ades Water } \\
\text { Indonesia }\end{array}$ & $\begin{array}{c}\text { Water Partners } \\
\text { Bottling }\end{array}$ & July 2004 \\
\hline
\end{tabular}

Source: BEJ, Indonesian Capital Market Directory

\section{3. Statistical Analysis}

To investigate the effect of government ownership on the cross-border performance, this study use ANOVA and mean comparison (post-hoc analysis) to test firm performance difference between groups of companies. The research design is shown in figure 1 . When comparison was done for state-owned bank (financial) institution (cell A) and state-owned nonfinancial institution (cell B), then the results would suggest industrial effect on acquisition performance, eliminating the effect of government ownership. Similar conclusion could also be drawn when cell $\mathrm{C}$ was compared with cell D. when cell A and cell C was compared, or when cell $\mathrm{B}$ was compared with cell $\mathrm{D}$, then the results would indicate the effect of ownership (state vs. privately owned), eliminating the effect of industry. To test the first hypothesis, we conduct means comparison of A vs. B vs. C vs. D. To test the second hypothesis, we conduct means comparison of $\mathrm{B}$ vs. C. vs. D.



Figure 1. Research Design

\section{Results and Discussion}

\subsection{Descriptive Statistics}

Table 2 and table 5 show the descriptive statistics for the financial ratios and abnormal returns respectively. The table shows that all of the ratios, except ROI of private non banks, are positive. In CR (current ratio) sizes of the means seem to be divided between industries. In QR and FATO state-owned non bank seems to be different compares to the rest of the sample. In TATO the private- non bank seem to be different from the rest. ROE of state-owned bank seem to be the lowest one. Table 5 shows that market react negatively to state-owned non bank and private bank acquisitions by foreign investors. 
Table 2. Descriptive Statistic - Financial Ratios

\begin{tabular}{|c|c|c|c|c|c|c|c|}
\hline & & $\mathrm{N}$ & Mean & Std. Deviation & Std. Error & Minimum & Maximum \\
\hline \multirow{5}{*}{$\mathrm{CR}$} & STATE-OWNED BANK & 12 & .29083 & .287164 & .082897 & .090 & .860 \\
\hline & STATE-OWNED NON BANK & 16 & 1.73937 & 1.790376 & .447594 & .040 & 7.760 \\
\hline & BANK NON STATE-OWNED & 16 & .16875 & .101382 & .025346 & .070 & .420 \\
\hline & NON BANK NON STATE-OWNED & 16 & 1.63813 & 1.168944 & .292236 & .330 & 4.070 \\
\hline & Total & 60 & 1.00383 & 1.314787 & .169738 & .040 & 7.760 \\
\hline \multirow{5}{*}{ QR } & STATE-OWNED BANK & 12 & .21167 & .260413 & .075175 & -.070 & .710 \\
\hline & STATE-OWNED NON BANK & 16 & 1.57687 & 1.758309 & .439577 & .020 & 7.640 \\
\hline & BANK NON STATE-OWNED & 16 & .09563 & .094514 & .023629 & -.020 & .310 \\
\hline & NON BANK NON STATE-OWNED & 16 & .63438 & .397659 & .099415 & .220 & 1.340 \\
\hline & Total & 60 & .65750 & 1.093864 & .141217 & -.070 & 7.640 \\
\hline \multirow{5}{*}{ FATO } & STATE-OWNED BANK & 12 & 9.19583 & 2.962755 & .855274 & 5.960 & 15.880 \\
\hline & STATE-OWNED NON BANK & 16 & .45938 & .147308 & .036827 & .200 & .730 \\
\hline & BANK NON STATE-OWNED & 16 & 5.15063 & 2.391456 & .597864 & 2.490 & 11.040 \\
\hline & NON BANK NON STATE-OWNED & 16 & 5.10000 & 3.399810 & .849952 & .710 & 12.360 \\
\hline & Total & 60 & 4.69517 & 3.888561 & .502011 & .200 & 15.880 \\
\hline \multirow{5}{*}{ TATO } & STATE-OWNED BANK & 12 & .12583 & .020652 & .005962 & .090 & .160 \\
\hline & STATE-OWNED NON BANK & 16 & .30375 & .081721 & .020430 & .130 & .500 \\
\hline & BANK NON STATE-OWNED & 16 & .12500 & .041473 & .010368 & .070 & .200 \\
\hline & NON BANK NON STATE-OWNED & 16 & 1.45375 & .486784 & .121696 & .590 & 2.330 \\
\hline & Total & 60 & .52717 & .620842 & .080150 & .070 & 2.330 \\
\hline \multirow{5}{*}{ DTA } & STATE-OWNED BANK & 12 & .89833 & .046872 & .013531 & .770 & .950 \\
\hline & STATE-OWNED NON BANK & 16 & .73125 & .431816 & .107954 & .500 & 2.200 \\
\hline & BANK NON STATE-OWNED & 16 & .91938 & .047815 & .011954 & .860 & 1.070 \\
\hline & NON BANK NON STATE-OWNED & 16 & .55750 & .150311 & .037578 & .230 & .830 \\
\hline & Total & 60 & .76850 & .276030 & .035635 & .230 & 2.200 \\
\hline \multirow{5}{*}{ OPM } & STATE-OWNED BANK & 12 & .18333 & .124924 & .036063 & .010 & .440 \\
\hline & STATE-OWNED NON BANK & 16 & .24875 & .216637 & .054159 & -.110 & .690 \\
\hline & BANK NON STATE-OWNED & 16 & .06062 & .297018 & .074254 & -.900 & .260 \\
\hline & NON BANK NON STATE-OWNED & 16 & .02688 & .178390 & .044597 & -.560 & .180 \\
\hline & Total & 60 & .12633 & .232247 & .029983 & -.900 & .690 \\
\hline \multirow{5}{*}{ NPM } & STATE-OWNED BANK & 12 & .17000 & .076277 & .022019 & .040 & .310 \\
\hline & STATE-OWNED NON BANK & 16 & .48500 & 1.114839 & .278710 & .010 & 4.630 \\
\hline & BANK NON STATE-OWNED & 16 & .03875 & .340311 & .085078 & -1.040 & .440 \\
\hline & NON BANK NON STATE-OWNED & 16 & -.02750 & .311309 & .077827 & -1.180 & .120 \\
\hline & Total & 60 & .16633 & .642880 & .082995 & -1.180 & 4.630 \\
\hline \multirow{5}{*}{ ROI } & STATE-OWNED BANK & 12 & .02083 & .009003 & .002599 & .010 & .040 \\
\hline & STATE-OWNED NON BANK & 16 & .12625 & .242401 & .060600 & .000 & 1.020 \\
\hline & BANK NON STATE-OWNED & 16 & .00500 & .040000 & .010000 & -.130 & .030 \\
\hline & NON BANK NON STATE-OWNED & 16 & -.00625 & .390980 & .097745 & -1.440 & .280 \\
\hline & Total & 60 & .03750 & .239212 & .030882 & -1.440 & 1.020 \\
\hline \multirow{5}{*}{ ROE } & STATE-OWNED BANK & 12 & .87750 & .770078 & .222302 & .010 & 2.100 \\
\hline & STATE-OWNED NON BANK & 16 & 2.37750 & 2.833458 & .708365 & .030 & 12.030 \\
\hline & BANK NON STATE-OWNED & 16 & 1.02563 & 1.620325 & .405081 & -.640 & 4.450 \\
\hline & NON BANK NON STATE-OWNED & 16 & 1.77625 & 2.488499 & .622125 & -.990 & 8.050 \\
\hline & Total & 60 & 1.55667 & 2.181668 & .281652 & -.990 & 12.030 \\
\hline
\end{tabular}




\subsection{Test of Hypothesis One (H1)}

To test the first hypothesis an analysis of variance was conducted using financial ratios and abnormal returns data. The purpose of the analysis is to investigate whether the mean performance of the state-owned bank is significantly different from the mean performance of the other types of companies. Performance was measured using (a) the difference between average two years financial ratios after and two years financial ratios before acquisition and (b) abnormal return -5 to +5 months surrounding the event month. The results are presented in table 3 , table 4 , and table 5 .

Table 3. ANOVA of Various Financial Ratios

\begin{tabular}{|c|c|c|c|c|c|c|}
\hline & & Sum of Squares & $\mathrm{df}$ & Mean Square & $\mathrm{F}$ & Sig. \\
\hline \multirow{3}{*}{$\mathrm{CR}$} & Between Groups & 32.352 & 3 & 10.784 & 8.672 & .000 \\
\hline & Within Groups & 69.639 & 56 & 1.244 & & \\
\hline & Total & 101.991 & 59 & & & \\
\hline \multirow{3}{*}{ QR } & Between Groups & 20.969 & 3 & 6.990 & 7.887 & .000 \\
\hline & Within Groups & 49.627 & 56 & .886 & & \\
\hline & Total & 70.596 & 59 & & & \\
\hline \multirow{3}{*}{ FATO } & Between Groups & 536.084 & 3 & 178.695 & 28.105 & .000 \\
\hline & Within Groups & 356.049 & 56 & 6.358 & & \\
\hline & Total & 892.133 & 59 & & & \\
\hline \multirow{3}{*}{ TATO } & Between Groups & 19.056 & 3 & 6.352 & 96.530 & .000 \\
\hline & Within Groups & 3.685 & 56 & .066 & & \\
\hline & Total & 22.741 & 59 & & & \\
\hline \multirow{3}{*}{ DTA } & Between Groups & 1.301 & 3 & .434 & 7.603 & .000 \\
\hline & Within Groups & 3.194 & 56 & .057 & & \\
\hline & Total & 4.495 & 59 & & & \\
\hline \multirow{3}{*}{ OPM } & Between Groups & .506 & 3 & .169 & 3.530 & .020 \\
\hline & Within Groups & 2.676 & 56 & .048 & & \\
\hline & Total & 3.182 & 59 & & & \\
\hline \multirow{3}{*}{ NPM } & Between Groups & 2.487 & 3 & .829 & 2.120 & .108 \\
\hline & Within Groups & 21.898 & 56 & .391 & & \\
\hline & Total & 24.384 & 59 & & & \\
\hline \multirow{3}{*}{ ROI } & Between Groups & .177 & 3 & .059 & 1.032 & .385 \\
\hline & Within Groups & 3.199 & 56 & .057 & & \\
\hline & Total & 3.376 & 59 & & & \\
\hline \multirow{3}{*}{ ROE } & Between Groups & 21.599 & 3 & 7.200 & 1.555 & .210 \\
\hline & Within Groups & 259.222 & 56 & 4.629 & & \\
\hline & Total & 280.821 & 59 & & & \\
\hline
\end{tabular}

Source: JSX 
Table 4. Results of the Multiple Means Comparison of Financial Ratios

\begin{tabular}{|c|c|c|c|c|c|}
\hline $\begin{array}{l}\text { Dependent } \\
\text { Variable }\end{array}$ & (I) Emiten & (J) Emiten & Mean Difference (I-J) & Std. Error & Sig. \\
\hline \multirow{12}{*}{$\mathrm{CR}$} & \multirow{3}{*}{ STATE-OWNED BANK } & STATE-OWNED NON BANK & $-1.448542^{*}$ & .425855 & .001 \\
\hline & & BANK NON STATE-OWNED & .122083 & .425855 & .775 \\
\hline & & NON BANK NON STATE-OWNED & $-1.347292^{*}$ & .425855 & .003 \\
\hline & \multirow{3}{*}{$\begin{array}{c}\text { STATE-OWNED NON } \\
\text { BANK }\end{array}$} & STATE-OWNED BANK & $1.448542^{*}$ & .425855 & .001 \\
\hline & & BANK NON STATE-OWNED & $1.570625^{*}$ & .394265 & .000 \\
\hline & & NON BANK NON STATE-OWNED & .101250 & .394265 & .798 \\
\hline & \multirow{3}{*}{$\begin{array}{l}\text { BANK NON } \\
\text { STATE-OWNED }\end{array}$} & STATE-OWNED BANK & -.122083 & .425855 & .775 \\
\hline & & STATE-OWNED NON BANK & $-1.570625^{*}$ & .394265 & .000 \\
\hline & & NON BANK NON STATE-OWNED & $-1.469375^{*}$ & .394265 & .000 \\
\hline & \multirow{3}{*}{$\begin{array}{l}\text { NON BANK NON } \\
\text { STATE-OWNED }\end{array}$} & STATE-OWNED BANK & $1.347292^{*}$ & .425855 & .003 \\
\hline & & STATE-OWNED NON BANK & -.101250 & .394265 & .798 \\
\hline & & BANK NON STATE-OWNED & $1.469375^{*}$ & .394265 & .000 \\
\hline \multirow{12}{*}{ QR } & \multirow{3}{*}{ STATE-OWNED BANK } & STATE-OWNED NON BANK & $-1.365208^{*}$ & .359494 & .000 \\
\hline & & BANK NON STATE-OWNED & .116042 & .359494 & .748 \\
\hline & & NON BANK NON STATE-OWNED & -.422708 & .359494 & .245 \\
\hline & \multirow{3}{*}{$\begin{array}{c}\text { STATE-OWNED NON } \\
\text { BANK }\end{array}$} & STATE-OWNED BANK & $1.365208^{*}$ & .359494 & .000 \\
\hline & & BANK NON STATE-OWNED & $1.481250^{*}$ & .332827 & .000 \\
\hline & & NON BANK NON STATE-OWNED & $.942500^{*}$ & .332827 & .006 \\
\hline & \multirow{3}{*}{$\begin{array}{l}\text { BANK NON } \\
\text { STATE-OWNED }\end{array}$} & STATE-OWNED BANK & -.116042 & .359494 & .748 \\
\hline & & STATE-OWNED NON BANK & $-1.481250^{*}$ & .332827 & .000 \\
\hline & & NON BANK NON STATE-OWNED & -.538750 & .332827 & .111 \\
\hline & \multirow{3}{*}{$\begin{array}{l}\text { NON BANK NON } \\
\text { STATE-OWNED }\end{array}$} & STATE-OWNED BANK & .422708 & .359494 & .245 \\
\hline & & STATE-OWNED NON BANK & $-.942500^{*}$ & .332827 & .006 \\
\hline & & BANK NON STATE-OWNED & .538750 & .332827 & .111 \\
\hline \multirow{12}{*}{ FATO } & \multirow{3}{*}{ STATE-OWNED BANK } & STATE-OWNED NON BANK & $8.736458^{*}$ & .962918 & .000 \\
\hline & & BANK NON STATE-OWNED & $4.045208^{*}$ & .962918 & .000 \\
\hline & & NON BANK NON STATE-OWNED & $4.095833^{*}$ & .962918 & .000 \\
\hline & \multirow{3}{*}{$\begin{array}{c}\text { STATE-OWNED NON } \\
\text { BANK }\end{array}$} & STATE-OWNED BANK & $-8.736458^{*}$ & .962918 & .000 \\
\hline & & BANK NON STATE-OWNED & $-4.691250^{*}$ & .891489 & .000 \\
\hline & & NON BANK NON STATE-OWNED & $-4.640625^{*}$ & .891489 & .000 \\
\hline & \multirow{3}{*}{$\begin{array}{c}\text { BANK NON } \\
\text { STATE-OWNED }\end{array}$} & STATE-OWNED BANK & $-4.045208^{*}$ & .962918 & .000 \\
\hline & & STATE-OWNED NON BANK & $4.691250^{*}$ & .891489 & .000 \\
\hline & & NON BANK NON STATE-OWNED & .050625 & .891489 & .955 \\
\hline & \multirow{3}{*}{$\begin{array}{l}\text { NON BANK NON } \\
\text { STATE-OWNED }\end{array}$} & STATE-OWNED BANK & $-4.095833^{*}$ & .962918 & .000 \\
\hline & & STATE-OWNED NON BANK & $4.640625^{*}$ & .891489 & .000 \\
\hline & & BANK NON STATE-OWNED & -.050625 & .891489 & .955 \\
\hline \multirow{12}{*}{ TATO } & \multirow{3}{*}{ STATE-OWNED BANK } & STATE-OWNED NON BANK & -.177917 & .097962 & .075 \\
\hline & & BANK NON STATE-OWNED & .000833 & .097962 & .993 \\
\hline & & NON BANK NON STATE-OWNED & $-1.327917^{*}$ & .097962 & .000 \\
\hline & \multirow{3}{*}{$\begin{array}{c}\text { STATE-OWNED NON } \\
\text { BANK }\end{array}$} & STATE-OWNED BANK & .177917 & .097962 & .075 \\
\hline & & BANK NON STATE-OWNED & .178750 & .090695 & .054 \\
\hline & & NON BANK NON STATE-OWNED & $-1.150000^{*}$ & .090695 & .000 \\
\hline & \multirow{3}{*}{$\begin{array}{l}\text { BANK NON } \\
\text { STATE-OWNED }\end{array}$} & STATE-OWNED BANK & -.000833 & .097962 & .993 \\
\hline & & STATE-OWNED NON BANK & -.178750 & .090695 & .054 \\
\hline & & NON BANK NON STATE-OWNED & $-1.328750^{*}$ & .090695 & .000 \\
\hline & \multirow{3}{*}{$\begin{array}{l}\text { NON BANK NON } \\
\text { STATE-OWNED }\end{array}$} & STATE-OWNED BANK & $1.327917^{*}$ & .097962 & .000 \\
\hline & & STATE-OWNED NON BANK & $1.150000^{*}$ & .090695 & .000 \\
\hline & & BANK NON STATE-OWNED & $1.328750^{*}$ & .090695 & .000 \\
\hline
\end{tabular}




\begin{tabular}{|c|c|c|c|c|c|}
\hline \multirow{12}{*}{ DTA } & \multirow{3}{*}{ STATE-OWNED BANK } & STATE-OWNED NON BANK & .167083 & .091206 & .072 \\
\hline & & BANK NON STATE-OWNED & -.021042 & .091206 & .818 \\
\hline & & NON BANK NON STATE-OWNED & $.340833^{*}$ & .091206 & .000 \\
\hline & \multirow{3}{*}{$\begin{array}{c}\text { STATE-OWNED NON } \\
\text { BANK }\end{array}$} & STATE-OWNED BANK & -.167083 & .091206 & .072 \\
\hline & & BANK NON STATE-OWNED & $-.188125^{*}$ & .084441 & .030 \\
\hline & & NON BANK NON STATE-OWNED & $.173750^{*}$ & .084441 & .044 \\
\hline & \multirow{3}{*}{$\begin{array}{l}\text { BANK NON } \\
\text { STATE-OWNED }\end{array}$} & STATE-OWNED BANK & .021042 & .091206 & .818 \\
\hline & & STATE-OWNED NON BANK & $.188125^{*}$ & .084441 & .030 \\
\hline & & NON BANK NON STATE-OWNED & $.361875^{*}$ & .084441 & .000 \\
\hline & \multirow{3}{*}{$\begin{array}{l}\text { NON BANK NON } \\
\text { STATE-OWNED }\end{array}$} & STATE-OWNED BANK & $-.340833^{*}$ & .091206 & .000 \\
\hline & & STATE-OWNED NON BANK & $-.173750^{*}$ & .084441 & .044 \\
\hline & & BANK NON STATE-OWNED & $-.361875^{*}$ & .084441 & .000 \\
\hline \multirow{12}{*}{ OPM } & \multirow{3}{*}{ STATE-OWNED BANK } & STATE-OWNED NON BANK & -.065417 & .083483 & .437 \\
\hline & & BANK NON STATE-OWNED & .122708 & .083483 & .147 \\
\hline & & NON BANK NON STATE-OWNED & .156458 & .083483 & .066 \\
\hline & \multirow{3}{*}{$\begin{array}{c}\text { STATE-OWNED NON } \\
\text { BANK }\end{array}$} & STATE-OWNED BANK & .065417 & .083483 & .437 \\
\hline & & BANK NON STATE-OWNED & $.188125^{*}$ & .077291 & .018 \\
\hline & & NON BANK NON STATE-OWNED & $.221875^{*}$ & .077291 & .006 \\
\hline & \multirow{3}{*}{$\begin{array}{l}\text { BANK NON } \\
\text { STATE-OWNED }\end{array}$} & STATE-OWNED BANK & -.122708 & .083483 & .147 \\
\hline & & STATE-OWNED NON BANK & $-.188125^{*}$ & .077291 & .018 \\
\hline & & NON BANK NON STATE-OWNED & .033750 & .077291 & .664 \\
\hline & \multirow{3}{*}{$\begin{array}{l}\text { NON BANK NON } \\
\text { STATE-OWNED }\end{array}$} & STATE-OWNED BANK & -.156458 & .083483 & .066 \\
\hline & & STATE-OWNED NON BANK & $-.221875^{*}$ & .077291 & .006 \\
\hline & & BANK NON STATE-OWNED & -.033750 & .077291 & .664 \\
\hline \multirow{12}{*}{ NPM } & \multirow{3}{*}{ STATE-OWNED BANK } & STATE-OWNED NON BANK & -.315000 & .238801 & .193 \\
\hline & & BANK NON STATE-OWNED & .131250 & .238801 & .585 \\
\hline & & NON BANK NON STATE-OWNED & .197500 & .238801 & .412 \\
\hline & \multirow{3}{*}{$\begin{array}{c}\text { STATE-OWNED NON } \\
\text { BANK }\end{array}$} & STATE-OWNED BANK & .315000 & .238801 & .193 \\
\hline & & BANK NON STATE-OWNED & $.446250^{*}$ & .221086 & .048 \\
\hline & & NON BANK NON STATE-OWNED & $.512500^{*}$ & .221086 & .024 \\
\hline & \multirow{3}{*}{$\begin{array}{l}\text { BANK NON } \\
\text { STATE-OWNED }\end{array}$} & \begin{tabular}{|l|} 
STATE-OWNED BANK \\
\end{tabular} & -.131250 & .238801 & .585 \\
\hline & & STATE-OWNED NON BANK & $-.446250^{*}$ & .221086 & .048 \\
\hline & & NON BANK NON STATE-OWNED & .066250 & .221086 & .766 \\
\hline & \multirow{3}{*}{$\begin{array}{l}\text { NON BANK NON } \\
\text { STATE-OWNED }\end{array}$} & STATE-OWNED BANK & -.197500 & .238801 & .412 \\
\hline & & STATE-OWNED NON BANK & $-.512500^{*}$ & .221086 & .024 \\
\hline & & BANK NON STATE-OWNED & -.066250 & .221086 & .766 \\
\hline \multirow{12}{*}{ ROI } & \multirow{3}{*}{ STATE-OWNED BANK } & STATE-OWNED NON BANK & -.105417 & .091276 & .253 \\
\hline & & BANK NON STATE-OWNED & .015833 & .091276 & .863 \\
\hline & & NON BANK NON STATE-OWNED & .027083 & .091276 & .768 \\
\hline & \multirow{3}{*}{$\begin{array}{l}\text { STATE-OWNED NON } \\
\text { BANK }\end{array}$} & STATE-OWNED BANK & .105417 & .091276 & .253 \\
\hline & & BANK NON STATE-OWNED & .121250 & .084505 & .157 \\
\hline & & NON BANK NON STATE-OWNED & .132500 & .084505 & .123 \\
\hline & \multirow{3}{*}{$\begin{array}{l}\text { BANK NON } \\
\text { STATE-OWNED }\end{array}$} & STATE-OWNED BANK & -.015833 & .091276 & .863 \\
\hline & & STATE-OWNED NON BANK & -.121250 & .084505 & .157 \\
\hline & & NON BANK NON STATE-OWNED & .011250 & .084505 & .895 \\
\hline & \multirow{3}{*}{$\begin{array}{l}\text { NON BANK NON } \\
\text { STATE-OWNED }\end{array}$} & STATE-OWNED BANK & -.027083 & .091276 & .768 \\
\hline & & STATE-OWNED NON BANK & -.132500 & .084505 & .123 \\
\hline & & BANK NON STATE-OWNED & -.011250 & .084505 & .895 \\
\hline \multirow{3}{*}{ ROE } & & STATE-OWNED NON BANK & -1.500000 & .821618 & .073 \\
\hline & STATE-OWNED BANK & BANK NON STATE-OWNED & -.148125 & .821618 & .858 \\
\hline & & NON BANK NON STATE-OWNED & -.898750 & .821618 & .279 \\
\hline
\end{tabular}




\begin{tabular}{|c|c|c|c|c|}
\hline \multirow{3}{*}{$\begin{array}{l}\text { STATE-OWNED NON } \\
\text { BANK }\end{array}$} & STATE-OWNED BANK & 1.500000 & .821618 & .073 \\
\hline & BANK NON STATE-OWNED & 1.351875 & .760671 & .081 \\
\hline & NON BANK NON STATE-OWNED & .601250 & .760671 & .433 \\
\hline \multirow{3}{*}{$\begin{array}{l}\text { BANK NON } \\
\text { STATE-OWNED }\end{array}$} & STATE-OWNED BANK & .148125 & .821618 & .858 \\
\hline & STATE-OWNED NON BANK & -1.351875 & .760671 & .081 \\
\hline & NON BANK NON STATE-OWNED & -.750625 & .760671 & .328 \\
\hline \multirow{3}{*}{$\begin{array}{l}\text { NON BANK NON } \\
\text { STATE-OWNED }\end{array}$} & STATE-OWNED BANK & .898750 & .821618 & .279 \\
\hline & STATE-OWNED NON BANK & -.601250 & .760671 & .433 \\
\hline & BANK NON STATE-OWNED & .750625 & .760671 & .328 \\
\hline
\end{tabular}

*. The mean difference is significant at the 0.05 level.

Source: JSX Data

Tabel 5. Descriptive Statistic - Abnormal Returns

\begin{tabular}{|c|c|c|c|c|c|c|}
\hline & $\mathrm{N}$ & Mean & Std. Deviation & Std. Error & Minimum & Maximum \\
\hline STATE-OWNED BANK & 71 & .0017772 & .03263780 & .00387339 & -.07400 & .07075 \\
\hline STATE-OWNED NON BANK & 71 & -.0002523 & .01778499 & .00211069 & -.05017 & .05813 \\
\hline NON STATE-OWNED BANK & 71 & -.0000983 & .01908251 & .00226468 & -.04556 & .04433 \\
\hline $\begin{array}{c}\text { NON STATE-OWNED NON } \\
\text { BANK }\end{array}$ & 71 & .0077315 & .02306972 & .00273787 & -.06574 & .07124 \\
\hline Total & 284 & .0022895 & .02395792 & .00142164 & -.07400 & .07124 \\
\hline
\end{tabular}

Table 3 shows ANOVA of the financial ratios. The table shows that six out of nine ANOVAs suggest that there are significant differences ( $p$-values $<0,05$ ) in performance means. Further investigation regarding which ratios have significant results was done and the results are available in table 4 . When performance is measured using profitability ratios the results are consistent with the hypotheses that there is no difference in performance. This finding supports opponents' view regarding the international takeover that the sale of state-owned banks would not improve the performance of the companies. It becomes clearer that the motivation behind the transaction is merely for satisfying IMF requirement, if not moral hazard. Table 5 shows results from capital market data. When performance is measured using market reaction (AR, abnormal returns) during the period of the transaction, AR shows also consistent finding with finding based on financial ratios data.

Table 6. ANOVA of Abnormal Returns

\begin{tabular}{|c|c|c|c|c|c|}
\hline & Sum of Squares & Df & Mean Square & F & Sig. \\
\hline Between Groups & .003 & 3 & .001 & 1.747 & .158 \\
\hline Within Groups & .159 & 280 & .001 & & \\
\hline Total & .162 & 283 & & & \\
\hline
\end{tabular}

Table 7. Results of Multiple Means Comparison of Abnormal Returns

\begin{tabular}{|c|c|c|c|c|}
\hline (I) Emiten & (J) Emiten & Mean Difference (I-J) & Std. Error & Sig. \\
\hline \multirow{3}{*}{ STATE-OWNED BANK } & STATE-OWNED NON BANK & .00202951 & .00400518 & .613 \\
\hline & NON STATE-OWNED BANK & .00187548 & .00400518 & .640 \\
\hline & NON STATE-OWNED NON BANK & -.00595435 & .00400518 & .138 \\
\hline \multirow{3}{*}{ STATE-OWNED NON BANK } & STATE-OWNED BANK & -.00202951 & .00400518 & .613 \\
\hline & NON STATE-OWNED BANK & -.00015403 & .00400518 & .969 \\
\hline & NON STATE-OWNED NON BANK & $-.00798385^{*}$ & .00400518 & .047 \\
\hline \multirow{3}{*}{ NON STATE-OWNED BANK } & STATE-OWNED BANK & -.00187548 & .00400518 & .640 \\
\hline & STATE-OWNED NON BANK & .00015403 & .00400518 & .969 \\
\hline & NON STATE-OWNED NON BANK & -.00782983 & .00400518 & .052 \\
\hline \multirow{3}{*}{ NON STATE-OWNED NON BANK } & STATE-OWNED BANK & .00595435 & .00400518 & .138 \\
\hline & STATE-OWNED NON BANK & $.00798385^{*}$ & .00400518 & .047 \\
\hline & NON STATE-OWNED BANK & .00782983 & .00400518 & .052 \\
\hline
\end{tabular}




\subsection{Test of Hypotheses Two (H2)}

To test the second hypotheses, we also used the same tables for the first hypotheses test. As mentioned before the ANOVA (table 3) shows significant results. Further means comparison analysis for the state-owned non-bank companies, the private bank companies, and the private non-bank companies indicate that when performance is measured using profitability ratios then the results is significant ( $p$-value $<0,05$ ). Performance of state-owned non bank companies is significantly different from the other two types of companies. When performance is measured using abnormal returns, performance of state-owned non bank companies is significantly different only from performance of private non-bank companies. These findings suggest that, compared to state-owned bank, the performance of state-non bank companies is significantly improved after the sale. In addition, as mentioned before, non bank industry is less regulated (compared to financial industry). As the result, new management can implement better strategies more dynamically.

\section{Conclusions}

Findings of this study support the notion that the sale of state companies, in particular banking companies, would not result in better performance. The reasons why the post acquitision performance of financial institutions was not significanly different, i.e., would not perform better compared to other companies, are twofold. First, banking industry is a regulated industry. Consequently, dynamics of the strategy implementation is limited and accounting measures may not reflect quite well what they should represent. Second, as criticism states, the transaction (the sale of Indonesia banks) was merely to execute IMF recommendation. Even ten years later (today) people are still questioning the necessary of the sale and whether the transactions were valued based upon the most appropriate prices. All hypotheses are supported with slight mixed findings. However, there are limitations in this study. Those limitations include small sample size and short period of observation. Hence, longer observation period is needed to really investigate the effects of the acquisitions by foreign investors.

\section{REFERENCES}

[1] Carow K, Heron R, Saxton T. Do Early Birds Get the Returns? An Empirical Investigation of Early-Mover Advantages in Acquisitions. Strategic Management Journal.2004;25:563-585.
[2] Datta D, Puia G. International Takeovers: An Examination of the Influence of Relatedness and Cultural Fit on Shareholder Value Creation in US Acquiring Firms. Management International Review. 1995; 35: 337-359.

[3] Eun C, Kolodny R, Scheraga C. Cross-border acquisitions and shareholder wealth: tests of the synergy and internalization hypotheses. Journal of Banking and Finance. 1996; 20: 1559-1582.

[4] Gray R, Kouhy R, Lavers S. Corporate Social and Environmental Reporting: A Review of the Literature and a Longitudinal Study of UK Disclosure. Accounting, Auditing and Accountability. 1995; 8 (2): 47-77

[5] Harris R., Ravenscraft D. The role of acquisitions in foreign direct investment: evidence from the US stock market. Journal of Finance. 1991; 46: 825-844.

[6] Hitt M, Harrison J, Ireland D, Best A. Attributes of Successful and Unsuccessful Acquisitions of US Firms. British Journal of Management. 1998; 9: 91-114

[7] King, D., D. Dalton, Daily C, Covin J. Meta-Analyses of Post-Acquisition Performance: Indications of Unidentified Moderators. Strategic Management Journal. 2004; 25: 187-200.

[8] Naomi K. The Shock Doctrine. Knpf Canada. 2008.

[9] Jeff M. International Financial Management. Thomson South-Western, Mason, Ohio. 2008.

[10] Marr W, Mohta S, Spivey M. An analysis of foreign takeovers in the United States. Managerial and Decision Economics. 1993;14: 285-294.

[11] Milne M J. Positive Accounting Theory, Political Costs, and Social Disclosure Analysis: A Critical Look. Unpublished Paper. University of Otago. 2002.

[12] Nusantaranews.com. 26/5/2009. Dengan Fakta, Kwiek Kian Gie Sudah Menang Debat Budiono.

[13] Schoenberg R. Measuring the performance of corporate acquisition: An empirical comparison of alternative metrics. British Journal of Management. 2006; 17(4): 361-370.

[14] Tuch C, O'Sulliva N. The Impact of Acquisition on Firm Performance: A Review of The Evidence. International Journal of Management Review. 2007: 141-170

[15] Vasconcellos G, Kish R. Factors affecting cross-border mergers and acquisitions: The Canada-U.S. experience. Global Financial Journal. 1996; 7(2): 223-238

[16] Wan KM., Wong KF. Economic Impact of Political Barriers to Cross-Border Acquisition: An Empirical Study of CNOOC's Unsuccessful Takeover of Unocal. Journal of Corporate Finance. 2009. Doi:10.1016/j.jcorpfin.2009.03.004

[17] Watts R, Zimmerman JL. Positive Accounting Theory. Prentice-Hall, Inc. 1996.

[18] Weston JF, Mitchell ML, Mulherin JH. Takeovers, Restructuring and Corporate Governance.4th ed. Pearson Prentice Hall. New Jersey. 2004. 